\title{
Accessing Alternatives: Latino Immigrant Financial Experiences in Virginia
}

\author{
Daisy Stevens Rojas \\ Cultural Expressions Consulting
}

This work addresses Latino immigrant use of tiendas and remittance services as alternatives to traditional consumer banking in Virginia. Qualitative and quantitative analysis strategies including ethnographic interviews, surveys and in-depth investigation reveal particular patterns among this population. Attention is paid to the reasons given by this population for alternative transaction methods. These center around a feeling of exclusion and mistrust in addition to difficulty with meeting the documentation requirements of consumer banks. Compared with statistical data gathered from a recent study conducted by the FDIC and the U.S. Census, information regarding individual and household income as well as savings and spending habits are offered to demonstrate the market potential of this group. Investigation into the use of 'tiendas', social networks and the significance of local demographics support these alternative methods and should be considered important aspects of the Latino immigrant experience when considering how to provide bank access to unbanked Latinos in Virginia.

\section{INTRODUCTION}

Based on a study performed through the Tayloe Murphy Center at the Darden School of Business in the Spring of 2009, findings among Latino immigrants in Virginia reveal that restriction to traditional banking and a feeling of discomfort among immigrants themselves has led to the creation of alternative transaction methods for this group. Social networks and avenues for success which have already been laid by previous groups of immigrants often direct newly arrived individuals to use the same methods. Among these are the purchasing of goods and services through tiendas or Latin grocers where many services are readily available without the hassle associated with typical consumer banks. Willing to pay the associated fees in order to remain within known and comfortable boundaries, customers are a devoted and reliable source of revenue. For those interested in targeting the Latino financial services consumer in Virginia, generalized national marketing strategies may not be effective. National data sets are not specific enough to adequately inform financial institutions of the demographic make-up in particular regions. Consumer banks have not yet been able to provide Latino immigrants with adequate checking or savings accounts. Field research among Latino ${ }^{2}$ immigrants in Virginia in the Spring months of 2010 sought to uncover how this group currently accesses financial resources, and 
manage personal finances. Overcoming the relationship obstacles and understanding particular needs among Latino immigrants in Virginia is vital to creating interest among this group. While language, lack of sufficient identification, and lack of education is a problem for many, it cannot be separated from the feeling of discomfort that is the greater concern for many respondents in our study.

The key features of the collected data are as follows:

1. General characteristics among Latinos in Virginia are these: foreign born, but less likely to be of Mexican heritage than of Central America, male, married, high school graduates (in a foreign country), speak English with difficulty but cannot read or write in English, full time worker, and of undocumented immigrant status.

2. Very few Latinos in Virginia have bank accounts in the U.S. Yet almost half save money both in the U.S. and another country.

3. Latinos in Virginia cite language barriers, lack of cultural understanding and lack of interest in Latino clientele among traditional institutions as major challenges to having a bank account in the U.S. Other obstacles include: documentation and social security requirements and fear of, or past experience of rejection.

4. Remittance is widely and regularly used as compared to other financial transactions, though rarely through traditional financial institutions.

5. Reasons given for choosing non-banks are as follows: they speak Spanish, have extended hours, convenient locations in the receiving country and non-banks offer reliable service.

6. Cultural norms influence Latino immigrant money management decisions.

A recent report by the Federal Deposit Insurance Corporation, (FDIC) "FDIC National Survey of Unbanked and Underbanked Households", provided information identifying the extent of outreach and service among consumer finance companies to unbanked and under-banked individuals as well as the challenges which affect the financial institutions' abilities to meet the needs of this population (FDIC 2010). "In the first national survey of banks' efforts to serve unbanked and underbanked individuals and families in their market areas, the FDIC found that improvement may be possible in certain areas" (Consumer Action 9 2009).

The organization of this paper is as follows. Section II details the field work, both ethnographic and gathered survey data. Section III describes the general characteristics of Latinos living in Virginia. Section IV provides information about the use of banks accounts both within the U.S. and abroad. Section V shares the challenges faced by Latinos in the use of traditional financial institutions. Section VI offers information about the use of wire transfer companies as an alternative to traditional banks. Section VII shares reasons Latinos choose nonbanks for financial transactions. This section also offers cultural explanations for the choice of money management strategies and trade relationships among Latino individuals and small business owners in Virginia. The conclusions in Section VIII will provide recommendations and suggest areas of further research.

\section{Methods and Field Research}

Primary data was collected through targeted surveys in various parts of Virginia from April 2010 to June 2010. The target groups included Latino individuals who are employed as day and farm laborers, service industry employees, construction, landscaping, child care and cleaning personnel and marginal family groups where one or more household members are undocumented. Thirty two surveys were conducted in Spanish and English among Latino 
individuals, and ten surveys were collected from Latino entrepreneurs in Virginia. Statistical data gathered from these surveys provided a basis for comparison to other national studies such as the recently released FDIC study on the unbanked (FDIC 2010). Qualitative analysis was conducted through twenty five interviews of Latino immigrants and business owners living and working in various locations in Virginia. Information gathered from these interviews facilitated observation of transactions at various financial service vendors in Virginia as well as several different banks. Observation of various tiendas ${ }^{3}$ in Charlottesville, Harrisonburg and Richmond Virginia provided additional source material for this study. Interviews of management and customers and a review of procedures at three different banks (Wachovia, Bank of America and BB\&T) also provided material and information relevant to the study.

\section{MARKET BACKGROUND AND DEMOGRAPHICS}

\section{Characteristics of Latinos in Virginia}

The projected Latino population of Virginia by the year 2050 is expected to be 2,085,030 (Federation for American Immigration Reform 2008). But among this population the task of defining all variety of individuals categorized as Latino with a single characterization is impossible. Many different classes, nationalities and income sets are represented among Latinos even within our small sample size. For instance one of our respondents needed a co-signature to open an account despite owning several properties and a jewelry sales company in her native Dominican Republic and paying for her children to be college educated in the U.S. But another interlocutor Roy, works in the U.S. as a painter and migrated to the U.S. after having lived in an extremely poor rural area in Central America. He did not attend primary school and never learned to read or write in either Spanish or English. Between these two and many others within this group, the only obvious similarity is a common language. But the shared experience of minority status does create some generalities especially among those who are new arrivals to the United States.

Understanding the cultural backgrounds of foreign born Latino individuals helps to reveal the behaviors and patterns associated with financial transactions made by this group in the United States. Overall among Latinos in the U.S. people of Mexican heritage represent $64 \%$ of the total population. But as described in Table 1 and the related graphs below (see Figure 1, 2 and 3), birth origin among Latinos in Virginia varies dramatically from the National average where Latinos of Mexican descent represent a significantly smaller portion of the population (only $26 \%$ ). Surprisingly, they are surpassed in numbers by people of Central American heritage who represent $27 \%$ of the Latino population in Virginia.

Many consumer banks may have developed strategies for working with Latino consumers based on National data sets for Hispanics or Latinos, but just as we recognize that these terms are labels for a generalized ethnic category, it must also be recognized that the peoples represented within that term are separately grouped and must be considered differentiated markets depending on their place of birth, residence, economic status, education, level of English fluency, and cultural norms. Based on the demographic distribution of Virginia as compared to the national figures, Individuals of Central American heritage are equally represented to individuals of Mexican heritage. The region of Central America is comprised of 7 different small countries and constitutes an area roughly $3 / 4$ the size of Texas. It has in the past been a unified nation and continues to operate with coordinated collective efforts on many international political platforms. 
FIGURE 1

POPULATION AND SURFACE AREA OF CENTRAL AMERICAN COUNTRIES

Surface

$\begin{array}{llll}\text { COUNTRY } & \left(\mathrm{km}^{2}\right) & \text { Population[1] } & \text { Density } \\ \text { Guatemala } & 108,890 & 12,728,111 & 116.8 \\ \text { Belize } & 22,966 & 294,385 & 12.8 \\ \text { Honduras } & 112,090 & 7,483,763 & 66.7 \\ \text { El Salvador } & 21,040 & 6,948,073 & 330.2 \\ \text { Nicaragua } & 129,494 & 5,675,356 & 43.8 \\ \text { Costa Rica } & 51,100 & 4,133,884 & 70.8 \\ \text { Panama } & 78,200 & 3,242,173 & 41.4 \\ \text { Total } & 523,780 & 40,505,743 & 77.3 \\ \text { Source: New World Encyclopedia 2008 } & \end{array}$

It is vital for Virginia consumer banks to understand the distinct characteristics of this group separately from those of Mexican heritage. Table 1 demonstrates:

TABEL 1

POPULATION ESTIMATES BY EASTERN REGION STATES

\begin{tabular}{|l|l|l|l|l|l|l|l|l|l|}
\hline & Total & Latino & Mexican & Puerto Rican & Cuban & Dominican & Cent. American & South American & Other Hisp. \\
\hline Entire U.S. & $285,691,501$ & $40,459,146$ & $25,894,763$ & $3,874,322$ & $1,437,828$ & $1,051,032$ & $2,901,679$ & $2,215,503$ \\
\hline N. Carolina & $8,270,028$ & 506,206 & 358,648 & 33,624 & 5,203 & 2,138 & 62,787 & $18,016,133$ \\
\hline S. Carolina & $4,059,838$ & 120,681 & 73,485 & 9,483 & 2,530 & 1,897 & 9,745 & 13,569 \\
\hline W. Virginia & $1,770,403$ & 10,935 & 5,547 & 2,647 & 479 & 0 & 117 & 462 \\
\hline Maryland & $5,421,869$ & 294,052 & 61,734 & 27,453 & 11,172 & 7,987 & 108,851 & 42,918 \\
\hline Virginia & $7,223,519$ & 418,027 & 110,522 & 49,836 & 16,185 & 5,391 & 111,957 & 78,896 \\
\hline
\end{tabular}

FIGURE 2

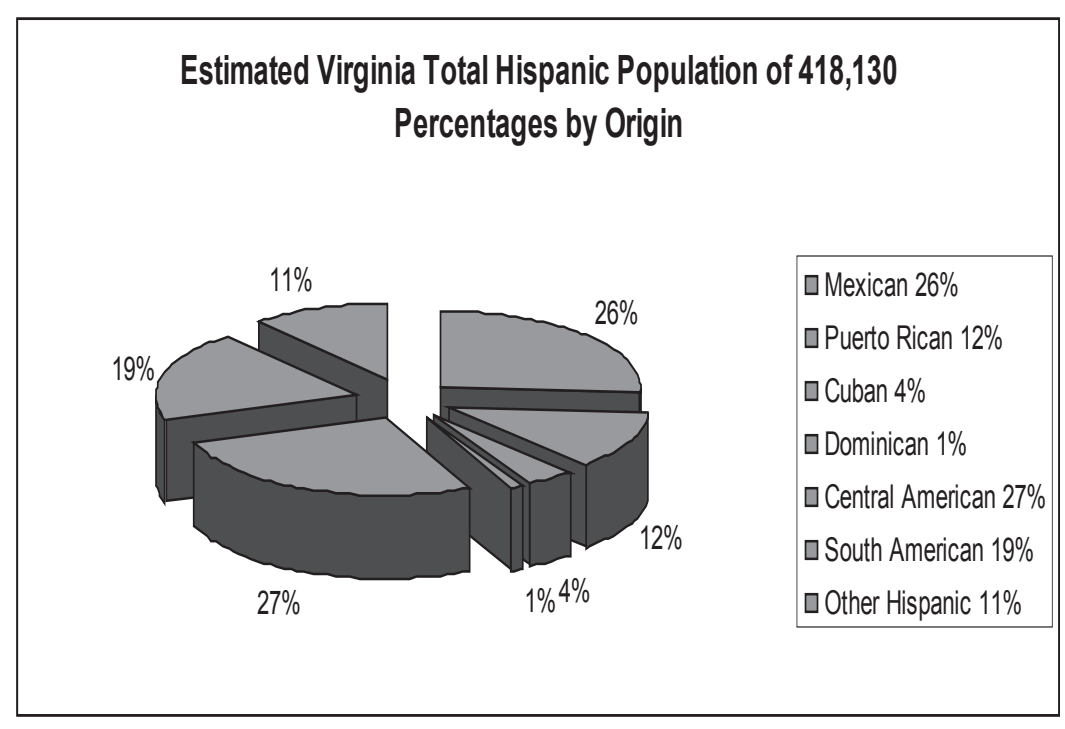

International Journal of Business Anthropology Vol. 1(1) 2010

Page 60 


\section{FIGURE 3}

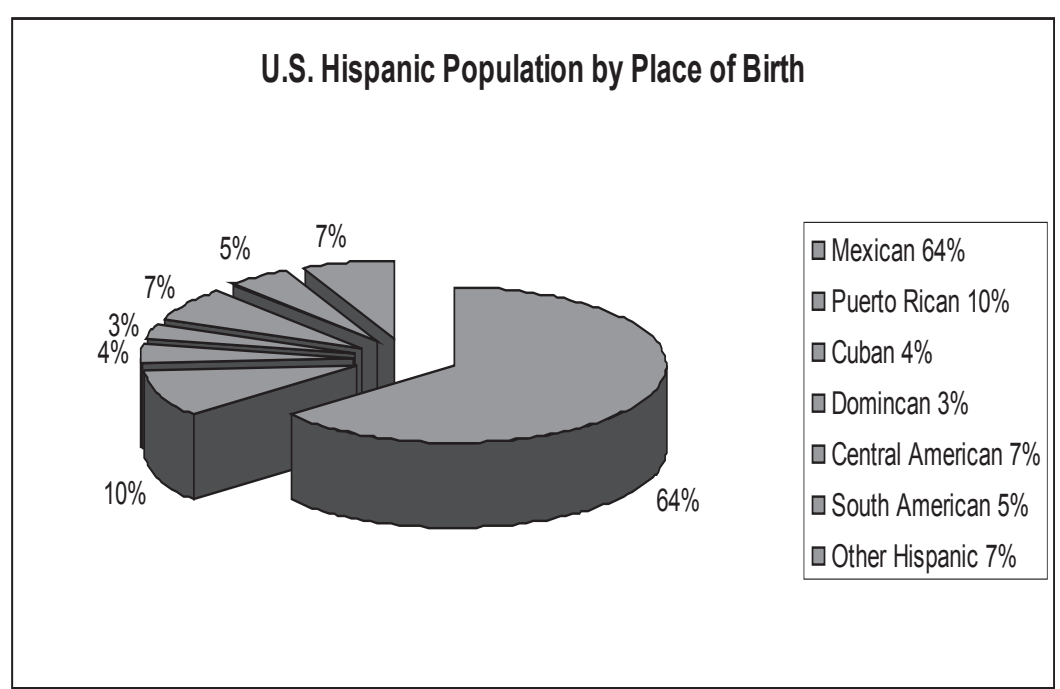

Source all: U.S. Census 2005

Among our respondents, findings related to gender, family status, and immigrant status are helpful for understanding lifestyle characteristics of the population. Knowledge of lived experiences among target groups assists consumer banks in tailoring services for particular customers. The statistics from our small sample provided some general characteristics among Latinos in Central Virginia. The graphs included below (see Figure 4) demonstrate the percentage of the population for each category.

FIGURE 4

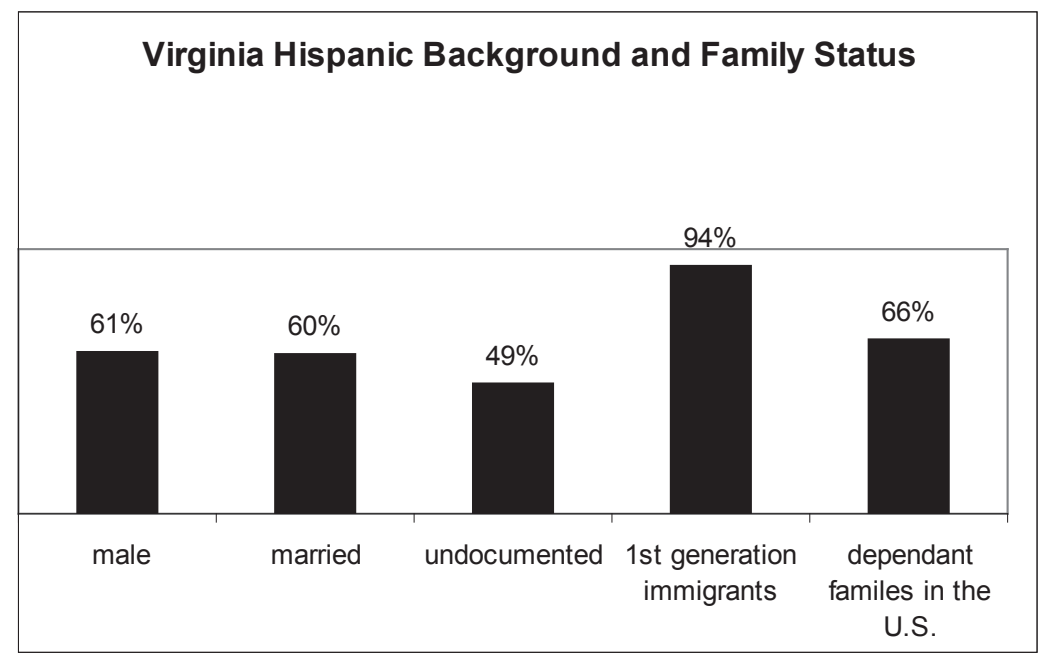

A majority of study respondents were born in a Latin American country other than the United States $(94 \%)$. Of those polled, most were male $(61 \%)$, with an average age of twenty nine, and married (60\%). Nearly half of all respondents answered that they were of undocumented legal 
status (49\%). And most reported that they also have dependent families living in the U.S (66\%). About thirty four percent of our respondents supported families outside the U.S. As the graph below demonstrates, in comparison to the general population of Virginia the family status of our sample are quite different:

\section{FIGURE 5}

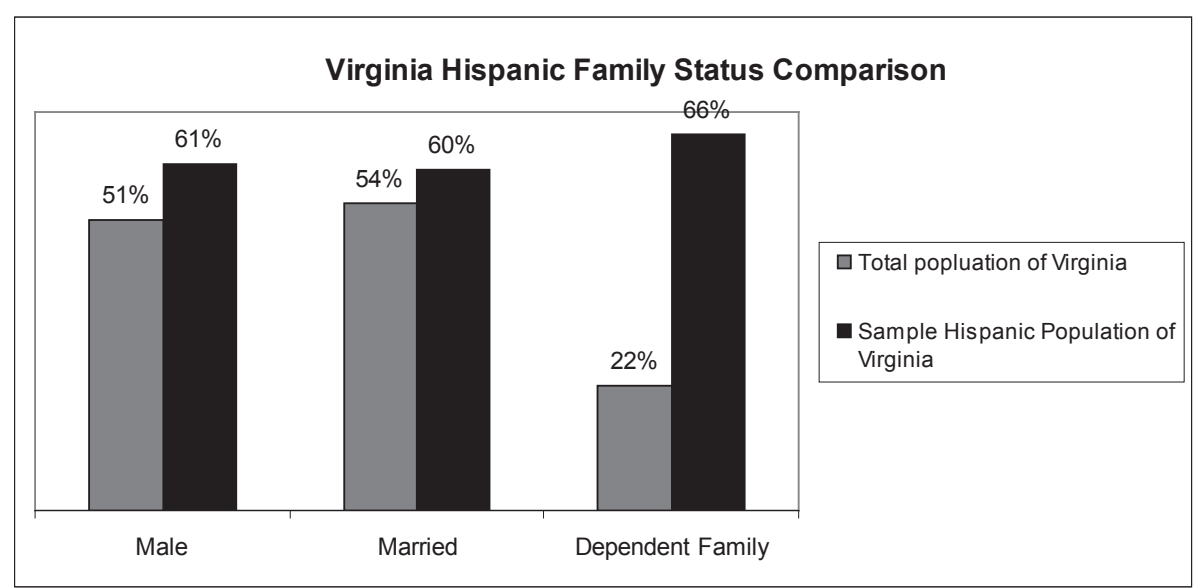

Of additional importance is educational background and language proficiency among Latino in Virginia. The following graph (see Figure 6) displays this information for our sample:

\section{FIGURE 6}

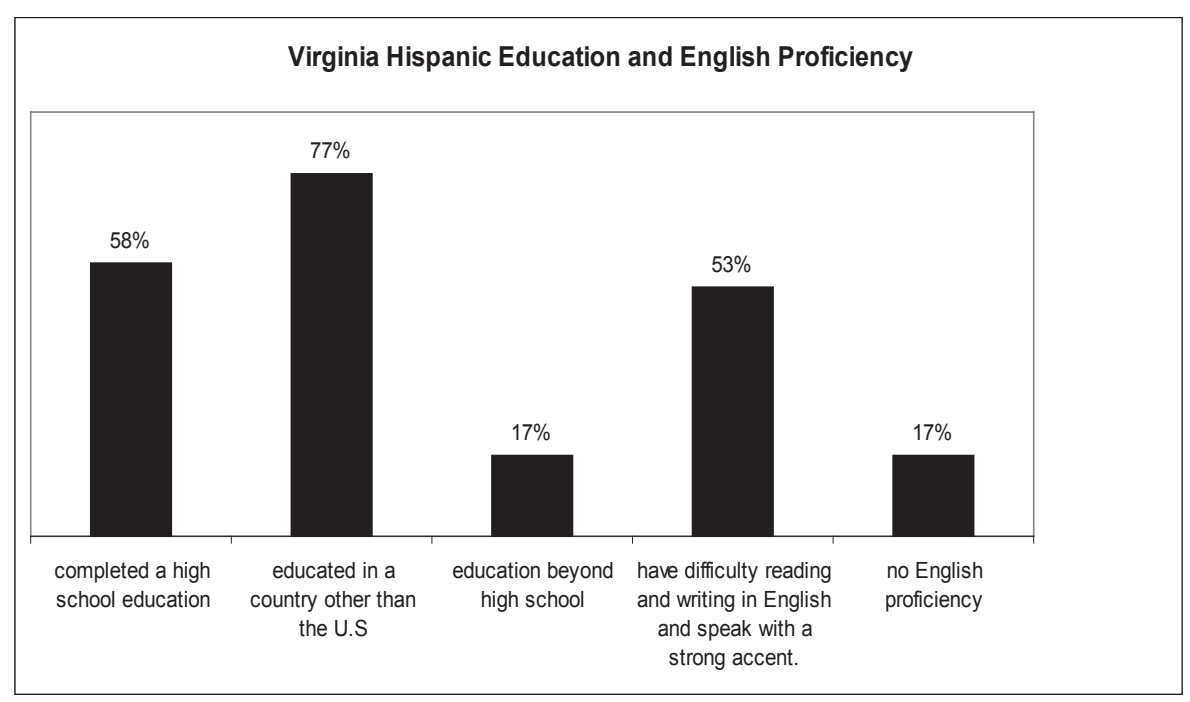

More than half reported that they had completed a high school education (58\%) but a majority (77\%) also responded that they had been educated in a country other than the U.S. yet in many rural areas of Latin America, free public education only extends to age eleven (Rojas 2009). About fifty three percent of respondents in our sample stated that they had difficulty reading and writing in English and spoke with a strong accent, seventeen percent stated that they could not read, write or speak English. 
Participant responses regarding money management strategies are also of interest. Carrie Jankowski's report "Against the tide--Currency use among Latin American immigrants in Chicago" reveals a trend among Latinos to hold cash within the home. She demonstrates a correlation between the currency demand for $\$ 100$ dollar bills flowing into Richmond Virginia and the growing population of Latino immigrants (Jankowski, et al., 2007). The use of cash for some Latinos is also culturally affected rather than solely due to logistical constraints. Latino communities heavily influence the decisions of newly migrated individuals as they attempt to quickly 'fit in'. Few are willing or interested in investigating consumer bank programs, preferring instead to use cash like their neighbors (Suro et al., 2002).

Among financial aspects of the household these facts were uncovered:

\section{FIGURE 7}

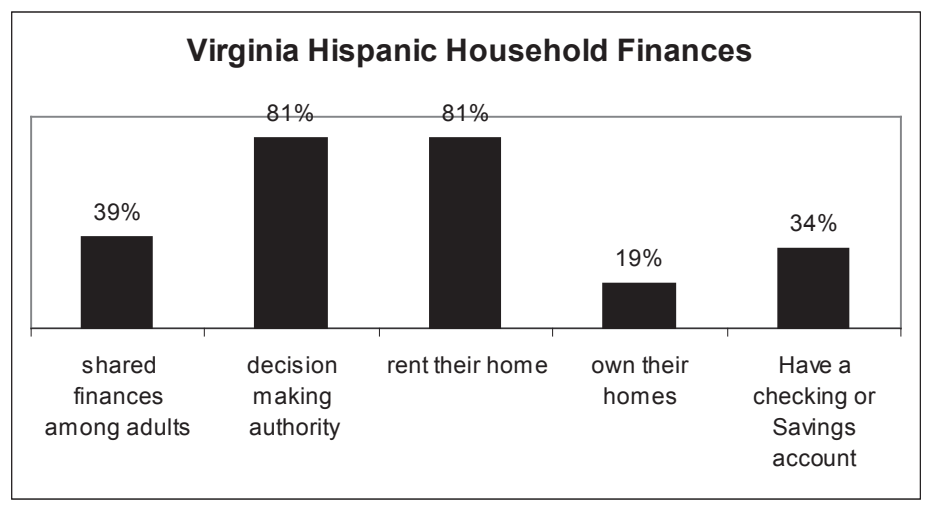

While it seems that fewer homes have shared finances (39\%), a high number reported that they had a large degree of decision making authority within the home (81\%). Most members of the population rent their home rather than owning it (81\%). Most individual s work full time (about 36.5 hours/week), and the average hourly wage is $\$ 12.00$ per hour $(\$ 22,512 /$ year). Typical employment is in services or trades such as cooking, cleaning, landscaping and construction industries.

In an interview with Roy (some names of respondents have been changed to protect privacy), several of these general characteristics were evident; but he also provided information particular to his experience.

Born in the Central American country of Nicaragua, Roy migrated to the U.S. ten years ago and currently works as a painter in Charlottesville Virginia. He lives in a small apartment with his two brothers and their wives (Roy is not married). Living expenses and rent are equally divided between the brothers but Roy pays for his own cell phone and personal entertainment expenses. The total monthly rent for the apartment is $\$ 800$, but split three ways, Roy's portion is only $\$ 266$ per month. He also sends a remittance of two to five hundred dollars to his mother on a monthly basis. Roy owns three vehicles, each less than ten years old. He pays for insurance on one of them. Roy works full time earning $\$ 14.00$ per hour but occasionally is without work during the winter months due to weather. He saves money in the form of cash in his home to pursue his dream of opening a car detailing and auto body shop in his native country. He has never had a bank account in the U.S., but on a recent trip to visit his family, he opened one in 
Nicaragua. Aside from saving money in his home, he trusts his mother to put the remittances he sends to her in his newly opened bank account. Roy cannot read or write in either English or Spanish and trusts others to help him with his transactions. Returning from a visit to his family earlier this year, Roy was kidnapped and held for ransom in Mexico. Fortunately, his brothers were able to pay the required $\$ 3,000$ dollars to release him within a few hours once the cash was wired to an account in Mexico. He pays off his debt to his brothers in monthly payments, desiring to do so as quickly as possible. (Interview with Roy Fabri)

Generalized statistics are helpful for determining market potential for Latinos in Virginia, but particular cultural characteristics and individual experiences among Latino immigrants shed light on both the areas of need and areas for opportunity. We may begin to see that the ideal approach to increasing financial services for this group requires a different way than has been previously attempted.

\section{ALTERNATIVE FINANCIAL EXPERIENCES}

\section{Banking in Virginia}

Banking among Latinos in Virginia is revealed to be a difficult endeavor. A very high number of Latinos in our sample group are unbanked in the U.S. and have never had a bank account in any country $(66 \%)$. Several reasons exist to explain why this group is not using banks for financial transactions. Among our respondents several had tried previously to open bank accounts and were denied (25\%). Many cited this fear of rejection, identification and documentation requirements and language barriers as major obstacles. But a surprisingly large proportion of responses cited lack of understanding for Latino culture and a feeling that banks do not want to do business with Latino individuals (78\%). These two options provided in our survey as reasons for not using banks to perform financial transactions were consistently selected by participants. Language and documentation requirements were also a problem for about forty seven percent of respondents.

Remarking on banking procedures, Alberto Ojeda notes that "(the) Latino community needs a bank that wants to do business their way" (Interview with Ojeda). In his own interview with Wachovia bank management last year in Richmond Virginia, Ojeda attempted to share knowledge of alternative methods for verifying identity (this is the main reason offered by Banks for refusing service to Latino immigrants) (Bank of America 2010, Horizontes 2009). He suggested acceptance of different forms of identification and checking names with international governments. The response he received from Wachovia was that they already had a system in place. "Management believes they know everything; they want Latinos to change" (Interview with Ojeda)

Mr. Ojeda states that financial institutions have an unrealistic idea that if all bank documents are translated and Spanish speaking customer service representatives are made available, then all that is necessary to invite patronage has been provided for their Spanish speaking clientele. But he maintains that financial institutions fail to recognize the potential among this group for making use of consumer banks for savings, remittance, bill paying and other transactions. Ojeda 
says consumer banks have an expectation that Latinos need to change their financial habits in order to use banks. With passion he states emphatically: "I won't change, this is my heritage." (Interview with Ojeda)

Mr. Ojeda's feeling of rejection based on his heritage stems from his perception of having been categorically profiled while attempting financial transactions with non-Latinos. This behavior of unawareness and possible exclusion of particular minority ethnic groups has been discussed many times in past and present literature (Johnson and Bash 1971, Schwab 1986, Ayers and Siegelman 1995, Yinger 1998, Oliveri 2009)

To consider this predicament, we investigated procedure at one branch of Bank of America in Charlottesville Virginia. This author attempted to open an account without a Social Security number and was told that it was not possible to do so. When asked specifically how an immigrant can open an account we were told that two forms of identification are required if a Social Security number is unavailable. These are limited to matricula consular cards from Mexico or Guatemala (no other country is acceptable), an International Driver's License, a passport and a valid visa. Additionally if an individual has lived in the U.S. for less than two years they must sign an affidavit stating their reason for coming to the U.S. Different approaches for handling this problem with establishing identity are based on the U.S. Department of the Treasury's decision to allow financial institutions to decide for themselves what forms of identification to accept. Despite this allowance, through the Office of Foreign Assets Control, the Treasury provides what is known as the "Specially Designated Nationals List" where financial service providers may check names to determine if an individual or company of foreign origin should be refused (U.S. Department of the Treasury 2010). Well known among remittance companies, this is the standard way to determine if a new client is eligible for service. A regional manager for Sigue corp explains:

"We use the D-list (common name for the Specially Designated National's List) when a new person comes in to make a wire transfer. They give us a picture I.D. and we check the name against the list. It takes a little time, but after they are cleared they don't have to do it again." (Interview with Mundo).

Over time some Latino immigrants in Virginia have been able to surmount a few of the obstacles to opening a traditional checking or savings account, such as providing acceptable identification. But fear of the system challenges savvy and affluent Latinos as well (Cheng, 2010). One study respondent who has lived in the U.S. for over ten years shared that he always has a problem when he uses different branches of his regular bank.

Despite owning several accounts for both business and personal transactions, Jorge was questioned at a different branch of Bank of America when attempting to open a guardian account for his young son earlier this year. Although he had his Virginia driver's license and several Bank of America debit cards with him, he was asked what his 'date of entry' was (referring to the first day he arrived in the U.S). "I told her I didn't have time to go home and get my passport" He felt very strongly that his accent and appearance caused the bank employee to assume that he may be undocumented or newly migrated. For this reason he rarely uses other 
branches, relying instead on personal relationships at his own local branch. (Interview with Jorge).

Some respondents $(36 \%)$ revealed that they had accounts in their country of origin before coming to the U.S., and a few (14\%), continue to maintain foreign accounts where they send remittances for savings. This provides a safe alternative to navigating the seemingly exclusive bank procedures among U.S. financial institutions in Virginia. Many Latinos are motivated to save money for various reasons. About thirty five percent of our sample group revealed that they save for emergencies and towards large purchases. Alternatives to saving in a financial institution are saving within the home or sending money via wire transfer to family members or friends for safekeeping. Both of these methods pose potential risks for Latinos who use them. Saving within the home makes communities susceptible to theft and violence when criminally minded individuals learn about the trend, and sending money to family or friends for safekeeping removes control from the fund owner, creating an opportunity for misuse or theft (Federal Trade Commission 2004). These concerns are deeply felt by the Latino community in Virginia and it seems that account ownership is a key component for creating a sense of economic and social security. In spite of rejection, fear and discomfort, fifty percent said it was very likely that they would open a U.S. bank account in the future. Additionally sixty five percent felt that account ownership would cause them to save more money.

\section{Facing Challenges: legal status barriers and cultural misunderstandings}

"An important distinction for most of these organizations (both public and private) is the 'legal status' of individuals... residency or citizenship is a factor in determining how to operate in certain circumstances (Rojas 2009, p.3)." Like Jorge's experience attempting to open an account for his child, many financial institutions require some form of identification that indicates legal status in the United States. Julia Peña shared that in addition to providing her passport and a foreign driver's license, she co-signed on behalf of her non-citizen mother to open an account at another bank in Charlottesville Virginia:

"It matters if you don't speak English and you look a certain way. If you speak Spanish they have a different way of doing things. After I opened the account, they sent notices in the mail requiring a social security number or a tax identification number. My mother is not a U.S. citizen or an illegal resident; we just ignored the notices." (Interview with Julia Peña)

Julia's story is unusual among our respondents because she is a U.S. citizen of middle class status and is equipped with cultural knowledge sufficient to navigate the system on behalf of her mother. For others who are of more limited means but still of Latino heritage these types of experiences are even more frustrating.

"Particular people in the bank have an attitude that they can't help because of the type of I.D. that we carry and even though it's legal it's not accepted. What are we supposed to do--carry a fake one? Sometimes there are people who are willing to help and others who are not. Bank of America accepts my husband's Mexican consulate card (matricula) but when we went to Wachovia to cash a government 
tax check they refused to accept the same I.D. They lost our business." (Interview with Perez)

Despite the difference in income levels and social background, the requirements for proof of residency or legal status create a feeling of different treatment for both of these individuals. Individuals classified as Latino have heritage or identification with one or more of 25 different countries within which a multitude of different customs, dialects and classes are represented (Yinger 1998, Harland Clarke 2010). This variety of peoples contribute to multiple and sometimes conflicting identities for many individuals. The attempt on the part of any institution to predict immigrant status based on last name, color, ethnic background or even accent is inadequate and offensive to many (Cai 2008, Oliveri 2009, Alfano 2010, Latino Decisions 2010). Attempting to overcome the social barriers at the same time one is attempting to deal with the procedural constraints is more than many individuals are willing or able to bear. Sometimes identified as Latino due to the surname Rojas, the author of this study has also had personal experience with the assumptions of poverty, lack of credit and a question of legitimacy experienced by many Latinos in Virginia. This recognizably different approach from individuals who have no indicators of Latino heritage is difficult for some to bear. Yet with such a large and mixed population of people who fall into this category their economic impact through financial transactions should not be ignored.

\section{Marketplace Potential among Virginia Latinos:}

- According to a 2008 Census report the population of people in Virginia who are Latino was roughly 500,000 with forty percent of that number identified as non-citizen immigrants (both authorized and un-authorized) Cai 2008).

- In addition to counted Latino residents, it has been suggested that the number of undocumented Latinos in Virginia today may be 250-300,000 (Cassidy and Okos 2010).

- Among respondents in our sample, about forty nine percent revealed that they were undocumented. The Pew Latino Center provided data that shows undocumented individual households in Virginia earning \$27,400 per year (Cassidy and Okos 2010).

Among our respondents who self identified as undocumented, individual income was reported as $\$ 22,325$. If the average household size among Latinos includes two wage earners, household income for this portion of the Latino population could potentially be $\$ 52,650$ /year. According to the $2009 / 2010$ Federal poverty guidelines there is a poverty threshold of $\$ 22,050$ for a family of four (average Latino family size) (U.S. Department of Health and Human Services 2010).

While we have already noted that Latino household income among our respondents is above the poverty line at an average of $\$ 44,650$, we also find that both the Pew Latino Center data of the sub-group undocumented Latino individual income as well as our estimate of un-documented Latino household income are greater than the Federal poverty threshold.

\section{Transnational Transactions}

Within our sample group as well as the larger Latino population as a whole, remittance is a popular financial transaction. Many recent Latino immigrants send remittances to family members living in their countries of birth. One Gallup Pole performed in Spring of 2009 shared the following graph demonstrating the long term remittance patterns among this group: 


\section{FIGURE 8}

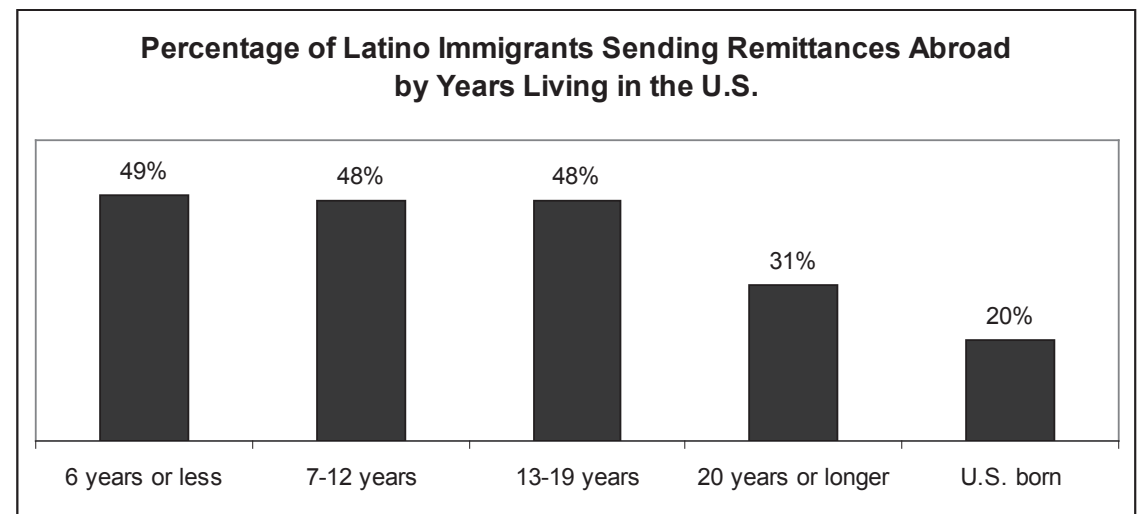

Copyright (C) 2010 Gallup, Inc. All rights reserved ${ }^{4}$ (Source: Torres, Gerver, et al 2009)

If we recognize that recently migrated Latinos are sending money abroad consistently for a sustained period of time (up to approximately 20 years), it is also important to our study to understand how and why this is so. We asked survey participants about saving patterns and bank use in other countries as well as the U.S. Most respondents reported that they did not have a bank account in another country when they lived there $(66 \%)$ but nearly half reported that they save money both in the U.S. and in their country of origin (45.71\%). Though some had attempted to use remittance services offered through local financial institutions, they quickly found it a cheaper and more convenient option to use a remittance service through a local tienda instead to send money to their country of birth for savings.

The banks are too expensive and slow. I had to pay $\$ 30$ to send money to my family. The fee was the same no matter how much money I sent. Besides, they needed me to fill out papers and show my identification. It only costs five percent of the cash amount to send my money through Sigue and it gets there in less than 2 hours. I never go to the bank to send money. (Interview with Acuña)

Like Mr. Acuña, many Latinos send money to Latin American countries on a regular basis through remittance companies. Among our respondents about fifty six percent send money to support family in another country. These remittances are sent mainly as cash to cash transfers through non-banks. An additional finding to note is that within our study sample about seventy eight percent of respondents stated that having a U.S. bank account would not change the amount of money they remit. But based on a 2009 study by Aimee Chin, Leonie Karkoviata, and Nathaniel Wilcox at the University of Houston "Impact of Bank Accounts on Migrant Savings and Remittances: Evidence from a Field Experiment," access to a savings account could reduce remittances among migrants who felt that receiving households in their native country were not abiding by their wishes (Chin, et al 2009).

\section{Use of the Tienda for financial transactions}

Several companies geared towards the Latino market are offered in local tiendas; often competing within the same storefronts. Vigo, Ria and Sigue Corp are the most frequently advertised, but many of our respondants also used Bancomer and Western Union for regular remittances. All of these providers promote their services primarily in Spanish within the tiendas. 
Posters, literature, receipts and service instructions are usually only provided in Spanish. Personnel to assist with transactions are bilingual, though Spanish is their native language. Remittance services are a staple commodity for the tienda. Companies compete with promotional material and functions to woo clients at tiendas and festival settings. Holiday sales are highly sought and require extreme public relations skills for sales managers to encourage use of their particular company. A regional sales manager for one remittance company provides 24 hour personal assistance to all his points of sale. He also plans and implements promotions for each of his participant stores, traveling to visit them frequently and offer support as necessary (Interview with Mundo)

We find that many of the unbanked have inexpensive alternatives to account ownership for their payment services. The majority of the unbanked are cashing checks for free, ironically, at banks and other institutions such as grocery stores. Few of the unbanked use the much-maligned check-cashing outlets as a regular source for cashing checks. (Prescott, 1999, p.50)

For Latinos in our study, check cashing and monthly remittances are usually transacted from a local tienda or Latin grocery store. Recreating a cultural norm for the Latino immigrant communities which they serve, these stores are usually Latino owned, family operated businesses. Tiendas fill a particular niche and are felt to be essential by their clientele. In addition to the original function of Latin American tiendas, the ones frequented by our study participants also provide:

- postal service,

- bill payment for water, electricity, cable/satellite, telephone service

- cell phone plans,

- international calling cards,

- remittance service,

- international shipping

- airline ticket purchases

Because of the difficulties associated with opening bank accounts, clientele of the tienda use another service, perhaps the most popular: check cashing. By providing this service, a unique and strategic relationship is formed. The minimal check cashing fee is well worth the expense to many Latino immigrants when so many other services are readily available and offered without prohibition. Likewise for the tiendas, offering this service along with courteous manners creates long-term customers who are willing to pay a few more dollars to take care of monthly bills, purchase food, send remittances, etc. An added bonus is the incentive to work with cash rather than debit or credit cards which are the usual currency at mainstream convenience stores. Because purchases are seldom made with debit or credit, the service fees charged to tiendas by credit card companies and issuing banks are minimal. Serving a population that doesn't use plastic saves significant expense as compared to other merchants. About two to three percent of the charge for plastic goes to banks and payment networks. Also known as an interchange fee, banks generate $\$ 40-\$ 50$ billion annually in income off of cards for these types of transactions (Martin 2009). Recognition of this symbiotic relationship is extremely important for understanding how to serve Latinos in Virginia. Particularly meaningful is the advice repeatedly 
given by Latino entrepreneurs in our survey that the most important piece of developing a successful business is to provide excellent customer service.

While the FDIC reports that: "A little over five percent of previously banked households closed their account because there was no bank near work or home, and about four and a half percent did so because they did not feel welcome or comfortable at banks (FDIC 25 2010)." Our study showed that a large majority of respondents choose non-banks for transactions (predominantly tiendas) rather than traditional financial institutions because they are more accommodating to their lifestyle. About eighty nine percent of sample participants cited these as major decision-making factors in favor of non-banks:

- convenience and familiarity,

- close location, reliable service,

- extended hours and weekends,

- they speak Spanish,

- they are faster in making funds available in other countries.

Speaking of her neighborhood shopping experiences, Ana Cisnero shares her memories of her home in El Salvador:

"In my barrio (neighborhood), there was a pulperia ${ }^{5}$ where we bought food items and sometimes ordered other things we needed for the house. Once in a while when we needed extra things like clothes, batteries or special tools we went to town to shop at a tienda. Everything you need is near the tienda. You can walk to the Post Office, the bank and the pharmacy if you want something." (Interveiw with Cisnero)

Ana's description of the pulperias and tiendas of El Salvador is a common experience in many Latin American Countries. In many areas, convenience vending in places with little vehicular transportation, limited electricity and sometimes located in remote locations is the norm. On the occasion that it is necessary to go to a more urban area for shopping, a visit to the tienda is an important social experience. These stores serve the important dual roles of supplying household necessities and opportunities for day-to-day survival through networking and trade relationships for local residents. (Coen, et. al, 2008, p 327).

The comfortable environments left behind among Latino immigrants are those of daily social interaction in plazas and town squares (Davis, 2000; Forsyth et al. 2001). Within the popular town square model of Latin American cities the tienda serves one function alongside several other necessary services within walking distance of each other. The tiendas in Central Virginia operate in a similar fashion; located within convenient distance to Spanish speaking immigrant communities. The social experience of conducting business in the local tienda is a "...series of overlapping local relationships, whereby traders and customers are simultaneously neighbors, as well as conceivable friends, relatives or acquaintances" (Coen, et al 329, 2008). In addition, time is not of the essence inside the tienda. Instead the development of long-term relationships requires that social niceties such as greetings and inquiries about family and health are part of the transaction experience (AJW Warehousing Inc 2006). Individuals within the Latino immigrant community depend on these permeable personal/professional relationships as they integrate into their local communities (Rojas, 2009, p.19). 
Bringing familiar service, products and ambiance to Latino immigrant communities has proven successful for these operations in combination with particular provisions for the lifestyles of immigrants. It is profitable for this group of retailers to serve the needs of 1 st generation Latino immigrant customers as they conduct specific financial transactions such as remittances. Because of the broad range of immigrants who send money on a regular basis to their native countries, the provision of remittance services is a major income source for the tiendas. And recognizing the reluctance and/or inability of many Latino immigrants to obtain a bank account due to lack of documents, language barriers, or distrust, transactions are usually conducted in cash (Jankowski, et al., 2007, p.7).

\section{RECOMENDATIONS AND CONCLUSIONS}

We have learned in this report about the spending and saving habits of Latinos in Virginia and understand that remittance services are a vital part of the financial transaction experience. Many banks charge more to send money than popular remittance services available within the culturally sympathetic tiendas. Additionally, among Latino Virginians, cultural patterns and established social networks heavily influence financial decisions. Friends, neighbors and family members often use the same service providers as their peers. Establishing personal relationships with customer service representatives with whom they do business creates a greater sense of trust and confidence that their needs will be met consistently without problems. Use of the tiendas for financial services is easy, convenient and perhaps a welcome relief for many newly migrated Latinos; offering one-stop shopping for check cashing, payment of household bills, remittance, cell phone service, etc., as well as culturally specific food and convenience items for purchase. Traditional financial service providers may find Latino consumers unwilling to leave the comfort of the tienda for an often intimidating experience within the consumer bank. However because half of respondents in our sample stated that they would open an account in the near future, potential for the consumer banking market exists and can be fostered if certain conditions are created. Particular circumstances and unimagined scenarios for traditional financial service providers are everyday life for individuals and Latino business owners alike. As they have learned to navigate the pitfalls of new surroundings, apply imaginative strategies and problem solving skills, so must consumer banks interested in capturing this exponentially growing market consider flexibility, innovation and open-mindedness as part of the customer service delivery. Of major importance in creating a comfortable experience for our respondents were these factors:

- Convenience and familiarity,

- Close location, reliable service,

- Extended hours and weekends,

- Spanish speaking representatives

- Rapid remittance service to locations in other countries.

\section{Recommendations}

By incorporating these basic provisions, consumer banks will begin to appear more welcoming to Latinos. In an effort to provide bank access to unbanked Latinos in Virginia, some recommendations for strategies are included here:

A. Continued research is necessary into the demographic and cultural background of particular groups represented in target areas. Specifically it is recommended that research be devoted to the Central American population of Virginia as this is often 
overlooked and undercounted due to the small size of independent countries where numbers are counted by separate nations rather than regionally.

B. The development of partnerships with tiendas to assist clientele in opening checking or savings accounts may be an effective way to reach Latino consumers. Providing a consumer bank window staffed with Native Spanish speakers inside a known and comfortable location may introduce unbanked Latinos to the possibility of bank access. Because many Latino immigrants have had little experience with banks prior to coming the U.S. or had unsatisfactory experiences in the past, this is an opportunity to provide education about services and procedures as well as establish a relationship of trust. Meeting clients 'on their turf' so to speak demonstrates a willingness to serve rather than exclude minority populations.

C. Provide branches of each bank located near neighborhoods with a "Latin feel" specific to Latinos in the area. Established financial institutions may observe what Latino neighborhoods are within proximity to particular branches and select one branch to designate as a Latino focused location. A welcoming ambiance may consist of Native Spanish speaking employees, prominently displayed Spanish signage, posters and brochures, music and art reflective of the particular demographic composition of the branch location (determination of the country representation among local Latinos would be necessary). Additional services familiar to Latino clientele should be available and competitively priced to local tienda service providers.

D. All bank branches in an area can create a welcoming ambiance by employing native Spanish speaking personnel with ties to the local community and providing prominent signage, posters and brochures. Improvement of Latino consumer relations with traditional financial institutions can be achieved through acknowledgement and representation among their ethnic group. Many Latinos will feel less trepidation approaching someone with whom they can identify; especially with a person already known to them. These employees may be trained to educate as well as offer services to potential clients. Time and attention should be taken into consideration when working with the Latino population. One part of the equation for the success of the tienda model is the understanding that this group develops social relationships while considering financial transactions. Time efficiency and lack of personal attention are a detriments to successful development of relationships thus also consumer confidence.

E. Development of a Credit Union dedicated to serving Latino clientele. This means going beyond simply providing more access to services and publicly advertising directly and exclusively to Latinos. It would be helpful if primary source information, just as in the tiendas, were provided in Spanish. A community credit union for Latinos will do best if able to offer all or most of the services already available in the local tiendas. These may include but are not limited to: remittance service, check cashing for non-members, and bill payment service. Through these culturally necessary services, bank access can be incorporated and potentially increased (LCCU 2001-2008).

\section{Conclusions}

Because Latinos in Virginia seem to highly value social experiences, attention and time dedication, employees at any institution seeking to encourage consumer banking among Latinos in Virginia should be trained to be culturally sensitive, respectful and patient when working with clientele. In order to foster long term relationships through personal interaction, it would be 
particularly helpful if at all times bilingual and native Spanish speaking employees are available to assist Latino customers who are unable to speak, read or write English. Special promotions may include financial education for the Latino population and a demonstrated interest in being a vital part of this growing community.

"...credit unions can reach out to the Latino market by offering needed products and services in a welcoming environment, focusing on: promoting financial literacy, providing culturally sensitive branches, and offering traditional and nontraditional banking products, including check-cashing services, at fair fees" (Credit Union National Association 2007).

Additionally helpful to financial institutions interested in serving Latino immigrants would be the adoption of the same tools used by tiendas. Included among these for determining customer eligibility is the Specially Designated Nationals List freely available at the U.S. Treasury Office of Foreign Assets Control website: http://www.ustreas.gov/offices/enforcement/ofac/sdn/

By far the most important consideration consumer banks might have when developing marketing strategies is that Latinos in Virginia currently have very different financial habits from mainstream America and even among sub-categories based on country of origin, location and social networks. As our respondent Alberto Ojeda cautioned, ignoring cultural heritage alienates Latino consumers (Interview with Ojeda). Excellent customer service is the key to developing relationships among individuals from what informed companies recognize as a vibrant market (Sigue corp, 2010).

Providing bank access to this portion of the population has the potential for mutual and symbiotic development. But organic growth requires an investment of time and dedication upon the part of interested financial institutions. A demonstration on the part of consumer banks and financial institutions to develop meaningful relationships with the Latino community within which they operate will yield long term customers and unmeasured growth. As our research demonstrates, Latino consumers value personalized service tailored to their needs and will share positive experiences among peers ultimately generating increased business for dedicated financial institutions.

\section{ENDNOTES}

1. This article is drawn from an earlier version entitled: Transactions en la Tienda: Alternatives to Traditional Financial Service Providers among Hispanic Immigrants in Virginia published by the Tayloe Murphy Center, University of Virginia. Grateful acknowledgement for financial support is made to the Tayloe Murphy Center at the University of Virginia, and for research support from Professors Gregory Fairchild and Kulwant Rai of the University of Virginia, Darden School of Business.

2. The use of the term 'Latino' is chosen for the sake of consistency with other categorizations of a non-homogenous group of individuals of Mexican, Puerto Rican, Cuban, Central American and South American heritage. This author desires to state that other labels for this socially constructed racial category include Hispanic, Latin@, Latin American, Latinoamericanos, etc.

3. Popular in Latin American countries, the tienda is a small-scale variety shop similar to a neighborhood grocer. In the U.S. the tienda is more of a specialty store stocking 
culturally specific food items such as sauces, spices, bread and dairy products popular in particular Latin American countries alongside general necessities. The items sold within the tienda vary according to the population representation in particular areas. For instance one tienda in Charlottesville VA catered primarily to Mexican and El Salvadorian tastes because of the majority representation of immigrants from these two countries in the surrounding neighborhood.

4. Results are based on telephone interviews conducted with 1,003 U.S. Latinos, aged 18 and older, between March 27 and May 6, 2009. This includes 545 Latinos who report having been born abroad and 453 who report having been born in the U.S. For analyses of immigrant groups based on years living in the U.S., sample sizes range from 106 to 184. The maximum 95\% margin of error for the smallest single group, incorporating a design effect of 1.82, is \pm 13 percentage points. Margins of error for the larger samples of 453 and 545 are both \pm 6 percentage points (Gallup 2010).

5. A mini storefront, smaller than a tienda, common in Latin American countries. It usually functions as a window or porch vending area with living quarters behind and is operated as a family business. In past research at least one has been found in rural areas for quick essential purchases such as salt, sugar, and dairy products. Telephone service, mail service, and limited cold storage is available for a fee.

\section{REFERENCES}

Alfano, Sean. (2010) "Arizona's anti-illegal immigration law, SB 1070, comes with how-to enforcement video for police" New York Daily News, July 1st 2010. NYDailyNews.com accessed 07/20/10.

American FactFinder. (2010). "Fact Sheet, Virginia: 2006-2008 American Community Survey 3Year Estimates". U.S. Census Bureau, 2006-2008 American Community Survey. http//factfinder.census.gov. Accessed on 07/19/2010.

American FactFinder. (2010). "United States, Census 2000 Demographic Profile Highlights, Selected Population Group: Hispanics or Latino (of any race)". U.S. Census Bureau, 2006-2008 American Community Survey. http//factfinder.census.gov. Accessed on 07/19/2010.

AJW Warehousing Inc. (2010). "The U.S. Latino Market” AJW E-News 001 Summer 2006.http://www.ajwwarehousing.com/uploads/mz/0B/mz0BZg7ZBUki4kSkbjvWiQ/LatinoMarket-Report---Full.pdf Accessed 07/23/10.

Ayres, Ian \& Siegelman, Peter. (1995). "Race and Gender Discrimination in Bargaining for a New Car. (1995)." American Economic Review, American Economic Association, vol. 85(3), pp. 304-21.

Bair, Sheila. (2003). "Improving Access to the U.S. Banking System among Recent Latin American Immigrants. Center for Public Policy and Administration University of Massachusetts-Amhurst. The Multilateral Investment Fund. 
Bank of America. (2010).Author investigation of bank service at one Charlottesville branch February 2010.

Cai, Qian. (2008). "Hispanic Immigrants and Citizens in Virginia Demographics and Workforce section Weldon Cooper Center, University of Virginia.

Cassidy and Okos. (2010). "Fiscal Facts: Tax Contributions of Virginia's Undocumented Immigrants" The Commonwealth Institute 2010. http://www.wilsoncenter.org/index. Accessed 05/25/10.

Cheng, Jim, Secretary of Commerce for Virginia. (2010). Introductory remarks for the The 2010 Virginia Hispanic Chamber of Commerce Business Conference: Strategic Alliances and Sustainability in Today's Economy. Richmond Virginia April 2010.

Chin, Aimee, Leonie Karkoviata, and Nathaniel Wilcox. (2009). "Impact of Bank Accounts on Migrant Savings and Remittances: Evidence from a Field Experiment" University of Houston and Chapman University.

Centro Internacional de Agricultura Tropical (CIAT), United Nations Environment Program (UNEP), Center for International Earth Science Information Network (CIESIN), Columbia University, and the World Bank. (2005). Latin American and Caribbean Population Database. Version 3. http://www.na.unep.net/datasets/datalist.php3 accessed on 07/23/10.

Coen, Stephanie E., Nancy A. Ross and Sarah Turner. (2008). "Without tiendas it's a dead neighborhood": The socio-economic importance of small trade stores in Cochabamba, Bolivia" Cities 25 327-339.

Consumer Action. (2010). "FDIC Study: Serving the unbanked and underbanked" $\mathrm{http}: / /$ www.consumer-action.org/radar/articles/study_serving_the_unbanked_and_underbanked/ Accessed: 07/26/2010

Credit Union National Association (CUNA). (2007). Hispanic Resource Center, News Updates 2007, http://www.cuna.org/initiatives/hispanic/hispanic_news07.html accessed: 07/27/10.

Credit Union National Association. (2006). "Targeting the immigrant market has potential" Hispanic Resource Center, News Updates 2006, http://www.cuna.org/initiatives/hispanic/hispanic_news07.html accessed: 07/01/10.

Davis, M. (2000). Magical urbanism: Latinos reinvent the US city. London, New York: Verso.

FDIC Unbanked/Underbanked Survey Study Group (2010). "FDIC National Survey of Unbanked and Underbanked Households." Federal Deposit Insurance Corporation 2010.

Federal Trade Commission. (2004). "Summary of the Proceedings" Hispanic Outreach Forum and law Enforcement Workshop. FTC Conference Center Washington D.C. 
Federation for American Immigration Reform (FAIR) Virginia: Census Bureau Data and Projection.(2008).http://www.fairus.org/site/PageServer?pagename=research_research29bb\#205 Oproject, accessed 05/27/2010.

Forsyth, A., Lu, H., \& McGirr, P. (2001). Plazas, streets, and markets: What Puerto Ricans bring to urban spaces in northern climates. Landscape Journal, 20(1), 62-76.

Furuseth, Owen J. and Heather Smith. (2006). "From Winn-Dixie to Tiendas: The Remaking of the New South" Chapter 1, Latinos in the New South: Transformations of Place Ashgate Publishing Company, Burlington VT.

Gardner, Peter (ILO Consultant). (2006). "Household Income and Expenditure Statistics (HEIS): A comparison of eight countries."

Harland Clarke. (2007). "The Secret to Reaching the Thriving Hispanic Market" Delivering Value, The Quarterly industry newsletter for clients of Harland Clark 1st Quarter 2007, accessed $06 / 14 / 2010$

Hogarth, Jeanne m., and Kevin H. O'Donnell (1997). "Being Accountable: A Descriptive Study of Unbanked Households in the U.S., "Proceedings of the Financial Counseling and Planning Education. (1997 Conference), pp. 58-67.

Jankowski, Carrie, Rice, Tara and Porter, Richard D (2007). Against the Tide- Currency Use Among Latin American Immigrants in Chicago. Economic Perspectives, Vol. 31, No. 2, Second Quarter 2007. Available at SSRN: http://ssrn.com/abstract=984936, accessed on 07/23/10.

Johnson Nathan and James Bash. (1971). "A Human Relations model for a Desegregated Group" Occasional Paper Series. Curry Memorial School of Education. University of Virginia Charlottesville Virginia.

Latino Community Credit Union. (2000-2010). http://atinoccu.org/en, accessed 07/27/10.

Latino Decisions. (2010). "Latino Voters Strongly Reject Arizona Immigration law 1070" posted on May 6, 2010 http://latinodecisions.wordpress.com, accessed on 07/19/2010

Martin, Andrew. (2009). "Card Fees Pit Retailers Against Banks" The New York Times, Business Section http://www.nytimes.com/2009/07/16/business, accessed 12/19/09.

New World Encyclopedia Central America. (2008).

http://www.newworldencyclopedia.org/entry/Central_America 2008 accessed 05/25/10.

Ojeda, Alberto. (2009). "Interview with Banking Management". Horizontes newspaper November, Richmond Virginia. 
Oliveri, Rigel. (2009). "Between a Rock and Hard Place: landlords, Latinos, Anti-Illegal Immigrant Ordinances, and Housing Discrimination. Vanderbilt Law Review Vol. 62:1:55.

Paulson Anna, Audrey Singer, Robin Newberry, Jeremy Smith. (2006). "Financial Access for Immigrants: Lessons from Diverse Perspectives" The Metropolitan Policy Program, Federal Reserve Bank of Chicago and The Brookings Institute.

Perez Huber, Lindsay and Maria C. Malagon. (2008). "Silenced Struggles: The Experiences of Latina and Latino Undocumented College Students in California" Nevada Law Journal Vol. $7: 841-861$.

Pew Hispanic Center and the Multilateral Investment Fund. (2002). "Billions in Motion: Latino Immigrants, Remittances and Banking" http://pewhispanic.org/reports/report.php?ReportID=13. Accessed 06/30/10.

Pew Hispanic Center Statistical Portrait of Hispanics in the United States. (2008). From source: Pew Hispanic Center tabulations of 2008 American Survey (1\% IPUMS). 2008.

Prescott, Edward and Tatar D. (1999). "Means of Payment, the Unbanked, and EFT i99”. Federal Reserve Bank of Richmond Economic Quarterly Volume 85/4 Fall.

Rai, Kulwant (2010). "Latinos/Hispanics in Virginia" Tayloe Murphy Research, University of Virginia Darden School of Business. Presented at the Virginia Hispanic Chamber of Commerce April 2010.

Rightminds.com. (2010)."Growing the Underserved Banking Marketplace: Reaching the Latino Consumer" www.rightminds.com. 2008. accessed 06/30/2010.

Rojas, Daisy (2009). "Latino American Citizens, Families and Communities: Negotiating Spaces in Urban Areas" included in workshop series Understanding Exclusion and Initiating Dialogue among Latino Populations, $6^{\text {th }}$ annual Public Anthropology Conference, American University.

Schwab, Stewart J. (1986 copyright 2001)."Is Statistical Discrimination Efficient? Cornell Law Faculty Publication. Cornell Law Library.

Sigue Corp. (2010)."Sigue Corporation Enters New York Money Transfer Market" Sigue.com 2010 http://www.sigue.com. Accessed on 05/27/2010.

Smith, Robert and Ellen Zienta. (2008). "Credit Where Credit is Due: The Latino Community Credit Union" University of Virginia Darden School Foundation, Darden Business Publishing, University of Virginia Charlottesville Virginia.

Suro, Roberto, Segio Bendixen, B. Lindsey Lowell, and Dulce C Benavides. (2004). "Billions in motion: Latino immigrants, remittances, and banking, " Pew Hispanic Center and Multilateral Investment Fund report. 
Torres, Gerver, Brett Pelham and Steve Crabtree. (2009). "Half of New Latino Immigrants to U.S. Send Money Abroad" Gallup Social and Economic Analysis, http://www.galllup.com/poll, September 22, 2009. Accessed 07/05/2010.

U.S. Department of Health and Human Services. (2010). "Poverty Guidelines, Research, and Measurement" http://aspe.hhs.gov/poverty/index.shtml 2010. accessed 07/15/10.

U.S. Department of the Treasury, Office of Foreign Assets Control (OFAC) "Questions about Specially Designated Nationals" http://www.treas.gov/offices/enforcement/ofac. Accessed on $04 / 06 / 2010$

Whitehead, Jayson. (1998). “Habla Espanol?”, C-ville Issue \#20.38 09/22/2-09/28/2008 Electorate. Charlottesville: University of Virginia Press.

Yinger, John (1998). "Evidence of Discrimination in Consumer Markets" The Journal of Economic Perspectives, Vol. 12 No2 (Spring 1998), pp23-40. American Economic Association. 1998. 